KAWISTARA

\begin{tabular}{lll}
\hline VOLUME 1 & No. 3, 22 Desember 2011 & Halaman 213-320 \\
\hline
\end{tabular}

\title{
JEWISH SUFISM IN MEDIEVAL ISLAM
}

\author{
Leonard C. Epafras \\ Program Studi ICRS Universitas Gadjah Mada \\ e-mail: leyonat03@yahoo.com \\ Bernard Adeney-Risakotta \\ ICRS - Indonesian Consortium for Religious Studies \\ e-mail: baryogya@gmail.com \\ Amin Abdullah \\ UIN - Sunan Kalijaga Islamic State University \\ e-mail: aminabdullah@telkom.net \\ Reuven Firestone \\ HUC - Hebrew Union College USA \\ e-mail: reuvenfirestone@gmail.com
}

\begin{abstract}
ABSTRAK
Artikel ini adalah riset kepustakaan dan merupakan indikasi awal pengantar pada suatu interaksi unik yang terjadi antara kelompok Yahudi terhadap Sufisme dalam kurun abad pertengahan di masa pemerintahan Islam. Di tengah gejolak relasi Yahudi dan Muslim yang didominasi narasi-narasi antagonis, dalam sejarah sebenarnya terjadi dinamika interaksi yang melampaui narasi konflik. Salah satunya adalah Mistisisme Yahudi yang mengadopsi Sufisme dalam pencapaian ideal-ideal spiritualnya pada abad pertengahan. Secara tentatif fenomena ini bisa disebut dengan "Sufisme Yahudi."
\end{abstract}

Kata Kunci: Sufisme Yahudi, Interaksi antaragama, Sejarah Agama, Relasi Muslim-Yahudi

\begin{abstract}
This article, based on literary research, is a preliminary examination of the unique interaction between Jews and Sufism that occurred in medieval times under Islamic rule. In the face of the present antagonistic relationship between Jews and Muslims which dominates the public sphere, it can be seen that historically there are some examples of interaction of the two groups in forms other than conflictual narratives. One of them is regarding Jewish mysticism, which adopted Sufism into their spiritual system during the medieval era. We might tentatively call this phenomenon "Jewish Sufism."
\end{abstract}

Keywords: Jewish mysticism, Interfaith interaction, History of Religion, Jewish-Muslim relationship 


\section{INTRODUCTION}

In the outskirt of Cairo, less than five kilometers eastern of Nile River lays an illustrious desert hills. Jabal al-Muqattam is a plateau and rocky promontories, between one hundred and twenty and one hundred and fifty meters height and steeped at the eastside. Since ancient times, it has been a place important to Egypt. The hills produced limestone that has been used to construct the Great Pyramids of Giza, which resides just fifteen kilometers westward of the hills. For thousands of years, the surrounding area was never absent from human settlements. The ancient city of Memphis was situated only across the Nile River, twenty four kilometers south of the hills. Memphis was the heart of ancient Egypt civilization that surrounded by the most famous pyramids of Egypt: Giza (al-Jīzah), Dahshūr, Șaqqāra, and Abū Șīr.

In the later era, a Roman fortress city of Babylon lies at the foot of the hills. In the first century CE it was soon became the center of Egyptian Christians (Coptic Christians). Nevertheless, only after the Arab conquest in the seventh century, the surrounding area expanded significantly and subsequently it became the central gravity of Islāmic Egypt.

Not only the place surrounding alMuqattam was politically strategic, the hills and its beautiful vista radiated another budding. The presence of the aforementioned ancient Egyptian "religious" center further boosted religious and spiritual significance of the hills for the later generations. The glow of the "numinous" blanketed the landscape of al-Muqattam was apparently thick enough to arrest the hearts of any spiritual seeker. It resides within the reach of the nearby urban centers, thus al-Muqattam simply a perfect place for individuals who wanted to make balance between spiritual and the carnal lives. Numerous caves and hide-holes lay in its bound, places where Christian hermits found it ideal for meditation.

Since pre-Islāmic era, various Christian orders also established monasteries and oratories in the hills. As a matter of fact, monasticism, both the eremitical and cenobitic persuasions had their origin in Egypt. Saint Anthony (ca. 251-356), an Egyptian hermit, has been an inspiration for thousands of Christians in the following centuries to follow his example. His monastic life in the "Inner Mountain" (probably Jabal Qulzum of the Eastern Desert) might be the model for hermits of al-Muqattam hills. "[T]heir cells in the hills were like tents filled with divine choirs," observed a scholar (Meinardus, 1999: 1; Harmless, 2004: 17, 93). Desert and wilderness like al-Muqatțam are crucial to the vision of monasticism. It enables the hermits to pursue spiritual perfection, battling the demons, and ascetical feats undisturbed by worldly matters (Dunn, 2001: 2-3, 12).

Miracles often associated to the hermits, such as the above Saint Anthony, which renowned for his numerous miracleworkings, presumably as the result of their ascetic life in the remote places. To this kind of hermetic monk, Bahīīā, apparently the young Muhammad during his business trip to Syria with his uncle Abū Țālib was first received the sign of his prophetic call and a warning against the Jews (Ibn Ishāq, 1968 (1955): 79-81). While, pre-Islāmic Arabs often sought blessings and healing from Christian hermits, early Muslim ascetics learn mystical knowledge from them as well (Andrae in Ayoub, 1986: 3).

The association of the hills with secluded lifestyles continued to the age of Islām, where it became a place for individuals and Șūfī orders (Ar. tarìqa) to pursuit their spiritual lifestyle (see Karamustafa, 2007: 1-7). A person like Ibn al-Fārid (1181-1235), a famous Șūfĩ and poet, contemporary with one of the greatest Șūfīs, Ibn 'Arabī (11651240), spent most of his time in the hills. Venerated as a saint he was also buried there, where his tomb is still visited until today. The controversial sixth Fatimid Caliph, Al-Hāakim (996-1021) was a frequent visitor, to which he spent many nights at al-Muqattam to practice Șūfīsm. The tragic and mysterious end of his life also associated to his spiritual practice. In the evening of February 12/13, 1021, as usual he rode on donkey to the hills alone to spend his secluded night, but never returned. 
The scent of mythical taste even stronger for Muslim, Jewish and Christian communities because they were considered the hills a sacred mountain. There were various legends and mysteries associated to various spots on the hills. Since al-Muqatțam was identified by some Muslims as Jabal al-Ṭūr in Qur'ān (QS. 19: 52), thus it related to the place God spoke to Moses. For some others, it is the place Moses confronted with the Pharaoh's magicians, the spot where Noah's Ark landed, the place where Abraham had been ready to sacrifice his son to God (Williams, 2002: 46), and the stop of the Israelite patriarch, Judah (Heb. Yehuda, Ar. Yahūda) in his way to meet his brother, Joseph (Ar. Yūsuf). The Jews, on the other hand retained a story of the origin of the hills that tells the hills' bareness was because it surrendered the vegetation to Mount Zion in Palestine (Behrens-Abouseif, 1963-2005: VII, 509-511). While the Coptic Church preserved a story related to the hills with God's deliverance from the evil scheme of a Jewish convert to Islām (Ar. mu'allaf), Ya'qūb ibn Killīs (930-991) upon Christian community (Meinardus, 1999: 202; Labib, I: 11).

It was under the spell of al-Muqatțam's charm, Batsir, a Cairene bellmaker regularly spent his time for spiritual pursuit. Like other murìd (Șūfís pulpit, the "committed one") of al-Kūrānī (d. 1367), he most probable stayed at one of two zāwiyas (convents of Dervish) managed by the Ṣūfī master. Al-Kūrānī revived the mystic way of al-Junayd (d. 910), a prominent early Șūfī that advocated the principle of strict poverty; the members of this order often called fuqarā' (Ar. "the poors").

Not only was the time Batsir generously invested at the hills problematic, especially for his family, he went so far to compel his wife to sell their properties and moved the family to the hills. His enthusiasm to Sunfīsm apparently threatened his family and forced his wife to send a letter to the nagid (Ar. $r a^{\prime}$ is al-yahüd), the head of Egyptian Jewish community at the time of Mamlūk David ibn Abraham Maimunī (Maimonides) to help to bring him back to his family. Since Batsir was a Jew of low status then the problem was gravely serious. The letter stated that:

... her husband [Batsir] was completely infatuated with (life on) the mountain [i.e. al-Muqatțam] with al-Kūrānī, in vain and to no purpose, a place where there is no Torah, no prayer and no mention of God's name in truth. He goes up the mountain and mingles with the mendicants, although these have only the semblance, but not the essence, of religion. The maidservant is afraid there may be there some bad man who may induce her husband to forsake the Jewish faith, taking with him the three children (Goitein, 1953: 46-49; Labib, II: 253)

The problem apparently was beyond the simple issue of "irresponsible" husband and father, but it touched the challenge of inter-confessional relationship as well. A Jew who attracted to the Sunfī's way was considered, according to the above letter stepping beyond the limit of his religious boundary, which in turn, could harm his Jewish identity. Another minor problem was implied to the mainstream Rabbinical Judaism perception toward mysticism-quapoverty. "[M]ingles with the mendicants," as the letter described the circumstance Batsir joined in, was probably struck the general Jewish sensitivity at the time.

Indeed, like two other religious traditions of Islām and Christianity, the Jews believed that they had an obligation to mitigate the suffering of the poor, as part of social, communal, and religious duties. However, Judaism at the time had no admiration to ascetic poverty and its manifestation, the begging, as Christian's monastic tradition and Șūīsm did (Cohen, 2005: 243-246). If we push further, perhaps there were other factors at play that can explain the way different religious traditions and culture interacted in the fourteenth century Egypt. However, it is the way Batsir attracted to go beyond his religious and communal boundary that the present article taken as the precedent.

The present undertaking will limit the description to simply giving a sketch, 
mainly a literature research and more or less in historically manner, deep and intimate relations between the Jews and Muslims in a specific mode of interaction. Though it may sound a two-way interaction, in fact it was a disparate relationship, in which the Jews' expectation was greater than the Muslims'. The mode of interaction in question is the Jews were grafting certain aspect of Șūfīsm into the Judaic native religious system; this is what Philip Alexander, a Jewish mysticism scholar from the University of Manchester dubbed the phenomenon "Jewish Șūfīsm" (Alexander, 2002: 717).

\section{DISCUSSION}

“Jewish Șūfīsm” Discourse

"Jewish Șūīism" is not a formal name or branch of Jewish mysticism recognized by Jewish and Islāmic studies specialists. The privilege of the term in this article is rest on its specific mode of interaction or aspiration that is not entirely fit into the mainstream Jewish mysticism, which in its technical term called Qabbala (Heb. "tradition"). Therefore, it is a loaded term and presented enclosed within quotation marks. Here, I will mainly see the process of interaction from the Jewish perspective, thus endow more space to describe the attitude and cultural gesture the Jews invested in Muslim domain.

Other categories such as Jewish and Islāmic mysticisms (Qabbala and Șūīsm) only cursory depicted, simply to demonstrate the degree of continuity and discontinuity with "Jewish Șûfīsm." The above introduction giving us at least two issues important to keep in our mind during this engagement.

First, it is important to reflect the way a place or geographical context provokes, induces, shares, and preserves an aura of sacredness across the time, religion, and culture. Al-Muqattam is an example of a place where the inter-confessional religious narrative endures. Probably not entirely comparable, though important to look at, is the case of pre-Islāmic and Islāmic Java Island. Indic civilization once a dominant culture in the pre-Islāmic Java Island, impressed in the place names, which adopted Sanskrit and its Old Javanese derivative names. The place like Imagiri/Himagiri and Yogyakarta, were replicated the Hindu's sacred mountain of Himālaya and sacred city of Ayodhyā in India (Gonda, 1952: 216-217).

Probably, also the case of the city of Kudus, with its al-Aqșā mosque in Central Java that rendered the quality of sixteenth century Ottoman Jerusalem, which in Arabic is called al-Quds, while at the same time prolong the sacredness of the former Hindu cosmology in the area (Kalus and Guillot, 2002: 27-56); the sacredness it rendered passed on to the next generations even after the region converted to Islām. In this point, therefore the relevant question in this discussion is what makes the medieval Egypt via the story of al-Muqattam conduced the possibility of religious interaction?

In a loose manner, the above account bring to fore the possible nourishing elements that began from the earlier era when the sanctity of a place, blended with the earlier religious traditions, provided precedence, even overlapping religious narratives that expanded the human religious experience. Nevertheless, it was not necessarily a peaceful handing over. Often the overpowering the earlier tradition by the later was the case, boosting the cynical side of inter-religious history.

Secondly, there was an indication of social, cultural, and political context that makes the Batsir spiritual experience possible. However, in this article I will not attend to this context and attention is turn to religious and cultural interaction of the Jews and their Șūfīstic context.

According to Paul Fenton, a scholar on Jewish-Muslim interaction, at the outset it was Judaism that influenced Șûfīsm in its formative period through a literary works called Isrā'îliyyāt: a collection of Rabbinical lore (Heb. 'aggada) and Jewish legends (Fenton, 1981: 1-2). For example, Mālik ibn Dīnār (d. 748), the student of the precursor of Șūfīsm, Hasan al-Basrī, was reportedly drawn Jewish sources in his work (Fenton, 1981: 
541). Soon afterward, however, roughly in the tenth century onward it was Sunfissm that commanding the spiritual course of the age and many Șūfī masters found Jews among their murìds (Fenton, 1981: 24). The famous al-Qushayrī (986-1074) for example, declared that he induced many Jews to embrace Islām (idem, 54n2). The story of Batsir, obviously was not an exception in this case.

Some of Șūfī masters apparently embrace the inter-confessional outlook that seen the differences of denominations even religious persuasions were less relevant for the seeker of the eternal truth. The ecumenical effect of the discourse of Sunfīsm was apparent in the death of the famous Șūfī master, Jalāl al-Dīn Muhammad Rūmī (12071273). His biographer, Aflāki reported the recital at the burial ceremony was not only taken from Qur'ān, but including passages from Psalms, Torah, and the Gospels by Muslims, Christians, and Jews sympathizers (Harmless, 2008: 172).

Inclination to Ṣūfīsm, in fact was part of larger Jewish and Muslim cultural engagement in the Medieval Islām. Fifteenth century Jewish mystic, Yōsef ben Shalom Ashkenazi provides us a hint of the tendency among some Jews to join Islāmic ritual.

Consider attentively the foolishness of those of our fellow Jews who not only praise the Muslim faith ... but when the Muslims profess their creed at prayer times in their mosques, these dim-witted Jews join them and recite "Hear O Israel." Furthermore they highly commend the nation of Muhaammad and consequently they and their children have become attached to the Muslims and they denigrate the holy faith of Israel ... I am astonished that even the dignitaries of our community praise the Muslims and testify to the latter's faith in one God (Fenton, 1981: 22).

The disapproval of such "trespassing" of religious identity was also shared by a prominent Medieval Jewish philosopher, theologian, and physician. Moses Maimonides (1137/8-1204). He displayed his cynicism to the excessive mystical practice conducted by
"Jewish Șūfīs" of his days that he rebuked, "those of our co-religionists ... who imitate the followers of other religions ... when they torment their body" (Fenton, 1981: 558).

From the two disapproval accounts we can deduce at least two things. First, the sympathetic Jews did not suffer any dissociated identity when they join the Muslims religious expression. They confirmed instead the Islāmic precept, but the confirmation was devised through their own Judaic tradition. The groups in question and the context of the occasions mentioned by Ashkenazi and Maimonides are unclear and require further investigation. However, it is obvious that during the Muslim ruling the religious atmosphere was conducive enough to allow such inter-confessional, enriching and voluntary interaction took place.

Secondly, unsurprisingly there were unsatisfied parties for such religious engagement. Trespassing religious identity by adopting and embracing other religious practice and world view considered, especially by the non-practitioners, dangerous and harmful. Established religious authority often charged such practice "heretic," "deviant," and other derogatory accusation. Part of the explanation of such attitude may be related to the minority status of Jews that preserving the "purity" of identity was all important.

Furthermore, the status of Sūfīsm in the Islāmic tradition, like any spiritual movements among Abrahamic traditions, was often problematic. Peculiar religious imagination, highly personal and intimate languages, claim of the intimacy between the creature and the Creator, and other exclusive expressions often caused numerous misunderstandings and put Șūfīsm at odds with the mainstream religious authority (Corbin, 1969: 7f). The execution of Persian Șūfī masters, Al-Ḥallāj (ca. 858-922) and Suhrawardi (1155-1191) were two extreme examples the effect of the collision between religious (and political) authority and Șūfīsm.

In our case above, probably Maimonides low opinion toward "Jewish Șūfīs" was 
simply sharing with the mainstream perception to Siufīsm. However, what is important in this regard is that both Jewish positions, i.e. the enthusiasm to adopt Islāmic and Șūfī practices and criticism to it, reflecting deeper struggle and dynamic of the Jews as diasporic people, as minority, and as "Islāmicate" Jews. "Islāmicate" Jews, following Marshall Hodgson terminology, was Jews that participated in Islāmic and Muslims cultural complex (Hodgson, 1977: I, 58-60).

This dynamic of embracing and enthusiasm, conflict and confrontation, both within the Jewish community and with Muslim dominant culture was part of identity formation in the "frontier." "Frontier" suggests the religious self that standing and roaming in the border of identity so as to envisioned the realm beyond by professing centrifugal movement, while at the same time within the attraction of centripetal force so as to preserving the existing tradition. It then implies the dynamic identity formation and becomes the framework to understand the formation of hybrid identity such as displayed by "Jewish Ṣūīsm."

On the other hand, though after the tenth century, Islāmic Ṣūīsm has came to its maturity, still in some rare cases, there were Muslims who linked their spiritual practice in one or the other way, to the spiritual practices of the Jews and Christians. Abū-Sa'îd Abu l'Khayr (967-1049), a Persian Șūfī, once caught by his father performing mystical discipline and ablution in an old Christian Cloister! (Peters, 1994: 315-316). Another case, Hasan ibn Hūd (1235/6-1297/8), a member of Muslim princely family from al-Andalus (Spain), learned spiritual practices from various sources of Muslim, Christian, and the Jews during his stay in Damascus (Goldziher, 1893: 218-220; Goitein, 1953: 40-41).

In addition, a trace of the above interaction in peculiar way appeared in an unexpected place and time. A sixteenth century Polish master of Jewish spirituality, Rabbi Jacob Joseph ha-Kohen of Polonnoy once told an anecdote.
... a pious man [Heb. hasid] met some people returning from a great battle with an enemy. He said to them, "You are returning, praised be God, from a smaller battle, carrying your booty. Now prepare yourself for the greater battle." They asked, "What is that greater battle?" and he answered, "The battle against the instinct and its armies."

The anecdote was written in Hebrew by the Rabbi in order to provide a context to the emergence of spiritual movement among East European Jewry, what was called Hasidut (Lobel, 2007: ix). The trace of the anecdote goes back to a prominent Medieval Jewish philosopher and spiritualist, Rabbi Bahya ibn Paqūda who lived in Saragossa, in the eleventh century Muslim's Spain (Ibn Paqūda, I: V, 5).

It was a story taken from his magnum opus, al-Hidāyah ilā farā'id al-qulūb (Guidebook to the Duties of the Heart, or simply Duties of the Heart). Student of Islāmic studies might easily recognized that the story is Islāmic origin and the pious man mentioned is none other than Prophet Muhammad himself. The Muslim original version goes like this: "upon returning from a battle, Prophet Muhammad remarked: 'We have returned from the lesser jihād (Ar. al-jihād al-aşghar) to the greater jihād (Ar. al-jihād al-akbar).' When asked what he meant by that, he is said to have replied, 'The greater jihād is the struggle against the self.'" The oft-quoted story is part of a hadith but from a weak tradition (Ar. $d a^{\prime}$ if) and nowhere in the canonical collections (Firestone, 1999: $16-17,139,19)$.

Nevertheless, relevant to our discussion, the later example might expand, with certain qualification, our understanding that the outcome of a cultural interaction in the past might be extended and transformed beyond the limit of time and place, and sometime emerged in the unexpected context, in the internalized form in other tradition.

\section{Islāmicate Jewry}

Islāmic tradition records the encounter between Prophet Muhammad and the Jews during his first mission to establish 
the message of Islām. The Jews challenged the Prophet mission and conflict among them was inevitable. However, the initial painful relationship between them seems disappeared after Islām swept the northern Arabia, in which some the Jews and "heterodox" Christians in the area received the coming of Islām as the liberator from the yoke of Roman Byzantine and Persian Sassanid -among the Palestinian Jews there some even expected the coming of Messiah (Wasserstrom, 1995: 48).

The success of Islām to embrace extensive area from Iberia to Persia, from Syria to North Africa into a single cultural and political mantle greatly affected the world Jewry. For the first time in Diaspora, large number of Jewish communities, of different persuasions and denominations, such as Rabbinical Judaism, Samaritans, "Hellenized" Jews, and other heterodox Judaisms united. Unlike in the Christians land, the Jews under Islāmic dominion took full participation in the Islāmic society, though, they had in the subordinate status as the people under protection (Ar. ahl al-dhimma) and subjected to special taxes and restrictions. In general, the Jews were enjoyed high tolerance relative to their brothers and sisters in the Christian lands. Hodgson provides useful framework through his term "Islāmicate," to understand the larger context that was the fertile soil for the above mode of interaction. In his term, Islāmicate "would refer not directly to the religion, Islām, itself, but to the social and cultural complex historically associated with Islām and the Muslims, both among Muslims themselves and even when found among non-Muslims" (Hodgson, I: 59).

In general terms, within this "Islāmicate" the Jews in different rate and impact in different place and time undergone the process of assimilation, acculturation, and in the linguistic field, creolization without, in religious qualification "Islāmicized." Arabization (qua Judeo-Arabic culture) was also the agent of unification of the world of Jewry and became the standard communication for internal affair and for the development of Hebrew grammar, and religious purpose. The Jews in al-Andalus (Iberian Peninsula) enjoyed the "golden age" of the Jewish culture, with the productions of religious, philosophy, mystical, literature, and medical texts. Along with the Christians, Jewish figures also close to the center of power, such as the above example of Moses Maimonides who was the court physician in the palace of Salāh al-Dīn ibn Ayyūb (ca. 1138-1193).

Judaism, notably the Rabbinical, and Islām concur that society and religion cohere to the point of no strict distinction between secular and religious matters. Comparatively speaking, both championed religious law more than other religious precepts. Meanwhile, Christianity from the era of Constantine (the Roman Emperor, 272-337) onward considered seriously the relationship between the church and the state. Religious law for Judaism and Islām becomes the guiding principle of all aspects of human's life. Though not entirely comparable, the study of halaka (lit. "path, way," the general term of Jewish law) by the Jews could be analogized to the study of figh (jurisprudence) by the Muslims; the Islāmic canonical law is called shari' $a$ that the literal meaning of the word, "path" or "way" equivalent to Jewish halaka.

The convergence does not end merely in the mental structure of religious material culture. It goes further to other features such as the basic notion of monotheism in the same term - though Christian might strongly consider her-/himself monotheist, it is a different kind and interpretation of monotheism. Both render God's will through the construction of social norms and particularly, through jurisprudence. Consequently, both established religious precepts around religious authorities to ensure the preservation of tradition and public execution of i.e. 'ulamā' (religious scholars), fuqahä' (experts on religious law), $q \bar{a} d \bar{\imath}$ (judge) among Muslim communities, though differ in the scope and power those roughly correspond with rabbanim, poseqim, 
dayyanim among Jewish communities (Kraemer, 2003: 38; Firestone, 2001: 122). Nevertheless, different context and historical precedence inevitably also produced different institutional formation and religious interests, let alone the dissimilar social status between the ruling society and the protected one.

On the other hand, the Jewish self perception in the medieval era probably also contributes to the emergence of spirituality discourse in both Islāmic and Christian spheres of influence. After Jewish failed rebellion to the Roman Empire and the failure of messianic endeavor that ended with the destruction of the Temple of Jerusalem in $70 \mathrm{CE}$ and the expulsion of the Jews from Judea after 135 CE, Rabbinical Judaism "proper" more or less established. The main pull of this mode of Jewish religious system, among others was its centered at Rabbis and Sages (religious consensus) and its cultural and religious productions, such as codified Oral Laws (Heb. Mishna), its interpretations and elaborations (Heb. Talmudim), biblical interpretations (Heb. Midrashim) and other Rabbinical literatures. Performing religious duties (Heb. mișvot) was one way to attain sanctification.

Rabbinical Judaism and early Christians out of the plurality of Judaism in the early millennium were the survivors of the destruction of the Temple in Jerusalem (mid second century CE). Both the early Christianity and Rabbinical Judaism mingled with the messianic idea, while the former hypostatized it in the figure of Jesus Christ, the latter in the complex system of rabbinical precepts and liturgy. Postdestruction Judaism in the traumatic event of the destruction resisted to any tendency of religious revivalism centered on a charismatic figure (e.g. Messiah), and to confirm of the expulsion as God's act of punishment to the Jews (Neusner, 1987: 265-282).

This worldview to a point endured in the medieval Jewry, though messianic expectation now became only one of the cores of diasporic Judaism. In the history landscapes, within Rabbinic and non-Rabbinic persuasion, revived the longing of messianic redemption, such as the case of some Jews who welcome Islām as the messianic liberator (supra), and 'Īsāwiyya movement (infra), and within Jewish tradition and liturgy messianic hope never died out. In Egypt for example, the mood of the Jews toward mysticism was coincided with the high expectation of messianic fulfillment. The era they lived was at the brink of millennium, a transition from the end of the fifth millennium to the sixth of Jewish calendar. The turn of millennium supposed to happen in 1 Tishrei 4999 (1 September 1239) (Fenton, 1998: 128).

Between the destruction of the Second Temple in the first century and the sixteenth century, Rabbinical Judaism having less appreciation to the historiography work; unlike the Christians and Muslims counterpart. The general attitude toward historiography is best represented by Maimonides contention: reading the profane history he considered as a "waste of time" (Yerushalmi, 1996: 33). As earlier discussed, the absence of Jewish historiography in medieval era in significant part was contributed by the self-understanding of being in the state of exile (Heb. galut). That of the major themes of available chronicles was persecution and suffering. This worldview seemingly shared also by Muslim historians, notably Ibn Khaldūn (1332-1406). He connected the Jewish exile with their loss of "group feeling" ("așabìyya). 'Așabìyya is a fundamental communitarianism that determines the rise and decline of a social group. Accordingly, instead of ensuring its survival, the loss of Jews' "group feeling" explained the Jewish degradation and legitimized their condition under Islāmic dominion (Ibn Khaldūn: 2005, 102-103, 425; Bland: 1983, 162).

Therefore, mystical attainment as demonstrated by the Jews apparently was part as a way to perform misvot, though in non-conventional way, very much like Șūfīsm that its main goal is to uphold the unity of God (Ar. tawhid ), and at the same time projected 
an alternative Jewish meta-history, along with messianism (Blumenthal, 2006, 1-4). The Islāmicate context provided further fertile soil of this religious engagement compares to medieval Christian context. The attachment to Islāmic culture allowed some Jews to join Islāmic religious practice and/or adopting Islāmic imaginary into their own system in relatively unrestrained.

\section{"Jewish Șūfism" in History}

In this part we will discuss several examples of Jewish individual and movements that in various degrees influenced by Siufīsm. Contemporary to the formative period of Șûfīsm around eight century, in Persia there was a Jewish sect that displayed similarity to Șūfīsm. Classical historian 'Abd al-Karīm al-Shahrastānī (10861153) in his book Kitāb al-Milal wa al-nihal (Book of Sects and Creeds), and Ya'qūb alQirqisānī (tenth century), a Karaite (Qūrā'îm) exegete in Kitäb al-Anwār wa al-Maraqīb (Book of the Light and the Watchtower), informed the emergence of a Messianic movement lead by a Jew. The leader, Abū 'İsā al-Ișfahānī (d. ca. 750) proclaimed himself a prophet (Ar. $n a b \bar{l})$, messenger (Ar. rasīl) and the awaited Messiah (Ar. al-masih al-muntadar). The goal of his movement was to free the Jews from Muslim power, which at the time lead by Umayyad caliphate (661-751). His message attracted many Jews, notably from Isfahan and they became a full-scale rebellion that seriously disturbed the caliphate. The caliphate army had successfully putting down the 'İsāwiyya rebellion, and soon the movement ended (Wasserstrom: 1995, 68-69).

After the failure, there emerged the Yudghānites (al-Yudgāniyyah) to continue the aspiration of 'İsāwiyya that was lead by the student of Abū 'İsā. Yudghān (Judah) al-Hamdānī, a Jew from Hamadan, Persia, lead the Yudghānites not only as a political movement but turned it into a spiritual movement, which in the large part at odds with Rabbinical Judaism. Yudghān apparently influenced by Sūfīsm, which at the time spread out widely in Persia. The main difference from other Judaisms was his preference to mystical interpretation of Torah. Yudghān also considered all beliefs, such as of those relating to paradise and hell were merely allegories (Broydé: 1901-1906, XII: 624).

Al-Qirqisān̄̄ assessed Yudghānite doctrine that, they "prohibit meat and intoxicating drinks and observe a great many prayers and fasts. They assert that Sabbaths and holidays are at the present time no longer obligatory, but (should be kept) only as memorial days" (Al-Qirqisānī 1930, Ch. XII). These two Jewish figures and groups, though in large part obscure, give us initial information regarding the encounter between the Jews and Șüfīsm in the early Islāmic history.

The second example of "Jewish Șūfīsm" is Bahya ben Joseph ibn Paqūda (eleventh century), a dayyan (Ar. qadi) and philosopher from al-Andalus (Spain). He wrote Al-Hidāya ila farā'id al-qulūb (Guidebook to the Duties of the Heart) between 1050-1090. In it the author exclaimed, "... for the duties of the limbs (Heb. ha'abarim) are limited in number, fewer than 613, but the duties of the heart are so many, their branches and offshoots are innumerable" (Ibn Paqūda 1996, I: I, 21). This was precisely the argument used by the Șūfī against (many) 'ulamā' that preferred "legalistic" approach over personal spiritual endeavor (Broydé, 1901-1906, II: 447-454; XI: 579-581). It may close, though not exclusively to the tension between understanding the apparent meaning of the Qur'ān (Ar. zāhir, "outward, exterior"), which is the main domain of 'ulama', and the underlying, esoteric dimension of it (Ar. bātin, "inner"), which is the main course of Șūfī practices.

In this regard Bahya probably influenced by the works of a group of Muslim encyclopedists, the Brethren of Purity (Ar. Ikhwān al-Șafä'). Its ten gates or sections in his book seems that corresponded with ten stages through which a Suûfī had to pass in order to attain that true and passionate love of God. This is also the aim and goal of Șüfí's ethical self-discipline. It is noteworthy that in 
the ethical writings of the Șūfīs, al-Qushayrī (986-1074) and al-Harawi there are sections which treat exactly the same subjects, the ten gates as those treated in the Duties of the Heart and which bear the same titles.

The ten gates of spiritual journey outlined as follows (Lobel 2007, 6). First, gate of Oneness (Ar. bāb al-tauhìd, Heb. sha'ar hayyihud). It is the foundational step of spiritual attainment, i.e. the perfect recognition of the Oneness of God (ikhlās al-tauhìd). Accordingly, the Oneness of God cannot be known in essence but only by the way of His action, that is through His works on Creation. Therefore, this notion is not only foundational for a spiritual journey but also a starting point to the contemplation of the works of creation that occupied the second gate.

Second, the gate of reflection/works of [creation] (Ar. bāb al-i'tibār, Heb. sha'ar habehina). For Bahya, the true nature of God is accessible by one power of intellect. He criticized people who rely on others' presentation of God blindly (Ar. taqlid, "imitation, unoriginal"). It is like, a line of blind people who guided by a single person who can see. This position, according to Diana Lobel makes Bahya an archetypical of medieval rationalist (Lobel, 2007: 248, 26).

Third, gate of serving God/obedience (Ar. bāb al-iltizāmu țấati llāhi, Heb. sha'ar 'avodat hashem). This part is regarding the true obligation and obedience to God.

Fourth, gate of trust/absolute reliance on God (Ar. bāb al-tawakkul, Heb. sha'ar habitahon) is regarding the absolute trust and total surrender to him (istisläm).

Fifth,gateofpurifying/wholeheartedness intention in action (Ar. bāb al-ikhlāṣ al-'amal, Heb. sha'ar yihud hamma'ashe).

Sixth, gate of humility (Ar. bābal-tawādu', Heb. sha'ar hakeni'a). The Oneness of God brings consequence to the subject obligation to have humility before God, and giving praise and glorification to Him.

Seventh, gate of repentance (Ar. bāb al-tauba, Heb. sha'ar hateshuba). This part discusses the obligation to repentance, to correct errors and failures.
Eight, gate of examination of conscience/ self-accounting (Ar. bāb al-muhāsaba, Heb. sha'ar heshbon hanepesh). The part of making a personal accounting before the God, as a way to urge our soul to fulfill its obligation to God.

Ninth, gate of abstinence/ asceticism (Ar. bāb al-zuhd, Heb. sha'ar haperishut). An advice to abstain from the world by emptying one's heart from worldly desires in order to dedicate oneself fully to God. In the ninth gate Bahya directly quotes sayings of the Sūfīs, whom he calls 'Perushim'.

Tenth gate of the love of God (Ar. bāb almahabba, Heb. sha'ar 'ahabat hashem). This is the peak of spiritual endeavor, the highest wish and greatest happiness, that is the true love of God.

Despite its apparent Șūfī influences and noted predilection of its ethical principles, Bahya did not go so far as to approve the ascetic practice of Șūfīsm. Stronger leaning to Șūīism was displayed by an Egyptian Jewish community in thirteenth and fourteenth century, led by Maimonidean family (Alexander 2002, 716-717). Abraham Maimonides (Abu'l Muna ibn Maymūn, 1186-1237), the son of the aforementioned Moses Maimonides, assumed nagid (the head of Jewish community, Ar. ra' is al-yahüd) after his father passed away. While Moses showed less interest on the mystical pursuit, he, in contrast, had strong inclination toward mysticism. Furthermore, in his work entitled Kifäyat al-'Ábidin (The Compendium for the Servants of God) he moved even further by claiming that the Islāmic path of mysticism, i.e. Sûfīsm was in fact, a practice lost from the Jewish tradition, but "revived" by the Muslims.

Thou art aware of the ways of the ancient saints of Israel, which are not or but little practiced among our contemporaries, that have now become the practice of the Sufis of Islām, on account of the iniquities of Israel .../ Do not regard as unseemly our comparison of that to the behaviour of the Sufis, for the latter imitate the prophets [of Israel] and walk in their footsteps, not the 
prophets in theirs .../ Observe then these wonderful traditions and sigh with regret over how they have been transferred from us and appeared amongst a nation other than ours whereas they disappeared in our midst. My soul shall weep ... because of the pride of Israel that was taken from them and bestowed upon the nations of the world (Fenton: 1981, 8).

His contention of the loss art of pietism in Jewish tradition, as the above remark went further by endorsing a "revivalism" among the Jews and advocating the adoption of Șûfīstic ways of attaining perfection and union with God, while simultaneously drawing from their well of Jewish heritages. On the other hand, it also displays a sincere believe that Șūfīsm was a continuation of the biblical prophetic tradition. He apparently did not aware of the development of earlier Qabbala in Southern France, thus employed Șūfīsm as the vehicle to his spiritual instruction (Scholem, 1987: 12).

His sons, 'Obadyāh ('Abd Allah) and David Maimonides (b. 1335) continued their father endeavor. 'Obadyāh wrote al-Maqāla al-Hawdiyya (Treatise of the Pool), and David wrote al-Murshid il al-Tafarrud (Guide to Detachment). The work of 'Obadyāh survived almost in entirety that it might help us to see the affinity of Jewish devotion with the Șūfī's counterpart.

The Treatise has been self-described as "a mystical vade mecum, a manual for the spiritual wayfarer along the Path to Godliness." It is an introduction to the spiritual life, and a guide to perfection "set thine aim to be the perfection of the soul," (Maimonides 1981, 75) - whose goal is spiritual progression to the union with God. The Treatise was written in Judeo-Arabic, that is Arabic with Hebrew script. Through the Arabic idiom, 'Obadyāh employed Șūfī's imaginary to expound his idea and to utilize technical vocabulary which differs from the mainstream Arabic.

The other affinity with Șūfīsm was his recalled the mystical practice of the prophet of yore. He employed many Biblical stories of journey of patriarchs and prophets as much the Șūfīs employed the story isrā' mi'rāj of the Prophet Muhammad. The Treatise furthermore, revealed the affinity of its spiritual manual with Șuffī's practices. Paul Fenton, the editor and translator of The Treatise reckons ten disciplines that conformed Șūfī practices (Fenton, 1981: 13-17):

First, Ablution (Ar. wudhü'; Heb. tebila). In the Islāmic tradition the sanction of purify oneself is based on the Qur'ān passage: “God loves those who turn to Him (al-tawbin), and He loves those who keep themselves clean (al-mutțahhirin)" (QS. 2:222). Concerning this issue, 'Obadyāh remarks:

Likewise a man who neglecteth his soul, abandoning it to its illness through his indulgence in worldly affairs, spending night and day buying and selling and so forth, will have nought but fearful and alarming dreams upon retiring to sleep/ It is for this reason that our pure [Ar. țahāra] and purifying Law hath cautioned us concerning all external and internal defilement. The former, such as menstruation and nocturnal emission, are to be cleansed through immersion [JA. țahāra wa-tebila] in a ritual bath [Heb. miqweh]. Thus Aaron and his descendants were enjoined 'to wash their hands and feet, that they perish not' [Exodus 30:21; this line is a copy of the standard Masoretic Hebrew text] this being the reason for the act of purification [שודיק; Heb. qidush]. For through the conviction man's soul acquireth after immersion that all veils, as it were, have been lifted, there ensueth a state similar to spiritual predisposition and communion with God. If not in need of immersion, then one must carry out the ablution [Heb. tebila] of hands and feet in order that the natural heat circulate in the body and arouse thereby the soul.

... Consequently, as a preliminary to prayer, it is fitting to prepare oneself through the ablution [Heb. birhisa] of one's hands and feet, restoring and arousing thereby the soul. (Maimonides 1981, 84 \& 102).

Ablution is a common religious feature and strongly related to the certain 
worldview of the relationship between man and the world, between man, and divine sanction. There are several Jewish-specific expressions on the notion of purity, such as tebila (ablution) and miqweh (ritual bath; also the immersion pool). Interesting enough the pair of țahāra (purity) and najāsa (filthy) for Islām, and tohar and tum'ah for Judaism is ease off the cultural difference between the two traditions, notably in the mystical discourse.

Muslim practice of cleansing before prayer, which includes washing the feet, does not strictly required by the Jewish law, except for special prayer in special religious day such as Sabbath. In the Coptic Church (Orthodox Church of Egypt), ablution is part of the Eucharist service. The priest who will perform the communion should follow the procedure of hand cleansing and wearing the clean clothes, while the communicants is expecting to purify their body and mind before approaching and taking the Body of Christ (Basilios 1981, I: 9).

Second, Prostration (sujūd). In the Qur'ān there are two fundamental gestures of the ritual prayer those are bowing $\left(r u k \bar{u}^{\prime}\right)$ and the more frequent, prostration (sujūd) (Tottoli 2001-2006, I: 254). This Muslim specific practice of reverence and humble adoration became also the practice of Jewish community under the tutelage of Abraham Maimonides and his sons. While the mainstream Judaism had abolished it since the destruction of the Second Temple of Jerusalem in the first century $\mathrm{CE}$, this group restored the practice by imitating the Muslim's.

Third, kneeling $\left(r a k^{\prime} a\right)$. In the daily liturgy the worshippers would remain kneeling like the Muslims.

Fourth, the spreading of the hand. At certain supplications the worshipper would stretch forth his hands with upturned palms.

Fifth, weeping. Apparently many of the first Șūfi were "weepers" and Abraham Maimonides advocates the Jews "weeping as a necessary expedient to prayer" (Fenton, 1981: 13).
Sixth, orientation. Another affinity to Islāmic practice was the way Jews worshipped in the synagogue. While the Muslims customarily stand and face the mihrāb (prayer niche), which indicates qibla (direction to Mecca), the Jewish worshippers would stand in rows, in Muslim manners and at all times face the Holy Ark, indicates the direction to Jerusalem.

Seventh, vigils and fasting. Some Șūfīs practiced al-qiyām wașsiyām ("standing and fasting") as part of the training of keep awake and concentrate.

Eighth, during khalwa period, to control the sleep and diet, and further, excessive prayers and meditations were part of the discipline, which common among Șūfī.

Ninth, incubation. Based on the passage from the Bible, i.e. Book of Samuel (3:3): "and Samuel was sleeping in the temple of the LORD" (JPS), the group expanded the practice of khalwa through incubation for period of time.

Tenth, dhikr: "recollection, remember." Dhikr is the center of Șūī transmission as manifestation of complex prayer and meditation practices. It is a recollection and recitation of the Arabic names of God (traditionally ninety nine names) mentioned in Qur'ān. Dhikr is mentioned frequently in Qur'ān as a command to humanity to remember God and his commands (Ernst and Lawrence 2002, 27). The basic formula of dhikr as a spiritual discipline is the negation ("there is no god," la illah) and affirmation ("but God," illallah) that recited repeatedly until the reciter elevated to the higher consciousness. Though the word semantically corresponds with Hebrew's zākar ("remember;" ركذ רכז however there is diametrical difference of the gravity of them. The imperative verb $z \bar{a} k \bar{r} r$ used throughout the Hebrew Bible is the keyword to understand Jewish collective memory and/or Jewish meta-history construction. There were different types of dhikr, and it may differ from tarīqa to tarīqa, not necessarily mutual exclusive though (van Bruinessen, 1992: 80ff). 
Furthermore, throughout The Treatise we find numerous Șūfī specific terms such as ishrāq (illumination), khalwa (spiritual retreat/ seclusion), fanā' (passing away/obliteration of the self), ittiṢāl (communion), țâlib (seeker/student), țarīq (the Way), mujāhada (mortification), sālik/sulūk (wayfarer), and so on (the complete list see Fenton, 1981: 131).

\section{CONCLUSION}

After attending all of the examples above briefly, we can conclude that what so called "Jewish Șūfīsm" was a particular kind of Jewish spirituality heavily made use of Șūfīs' vocabulary, images, and practices that not entirely fit into the Qabbala. The adoptions of Șūfīs' vocabulary should be seen as instrumental in order to help the Jews expounded their own spiritual experience. The usage of JudeoArabic, as specific Jewish language in Islāmic domain and the replacement of the earlier Aramaic helped to boost Jewish religious intensity through language.

Mysticism, in its generic term as vision and intuition of the personal attainment to the reality of God often so appealing that s/ he may use all necessary means to grasp it. Though a mystic undergoes very personal and unspeakable experience, the meaning of this kind experience in large part remains public and need a container to express it. It does not prevent her/him to obtain certain "vehicle," "frame of reference," "construction" through philosophy and cognitive construction to help her/him to say something better about the reality of the transcendence. In this, receptive to other mode of thinking and influence is ensued. The way each cross-confession or making the mutual self-definition is highly complex but also feasible since none of religious tradition living in isolation.

The "Jewish Șūfīsm" discourse is only an example of a symbiotic process where each party "enriched by" the other and found the vehicle to boost its own indigenous devotion. If this situation properly understood, we may see a genuine cultural conversation between the two traditions. After all, the mystics of any religious traditions believe the root of human existence deeply entrenched to the transcendence, as a Sūfĩ express it, "trees have their roots in the sky” (Glassé:1989, 378).

\section{BIBLIOGRAPHY}

Alexander, Philip S., 2002, "Mysticism," The Oxford Handbook of Jewish Studies edited by Martin Goodman, Jeremy Cohen and David Sorkin, Oxford: Oxford University Press.

Al-Qirqisānī, Yaqub, Book of the Light and the Watchtower (Kitāb al-Anwār wa al-Maraqib), Complete English translation in Leon Nemoy, 1930, "Al-Qirqisānī's Account of the Jewish Sects and Christianity," Hebrew Union College Annual, 7, 317397.

Ayoub, Mahmoud, 1986, “Uzayr in the Qur'ān and Muslim Tradition" In Studies in Islämic and Judaic Traditions edited by William M. Brinner and Stephen D. Ricks, 3-18, Atlanta: Scholars Press.

Basilios, Archbishop, 1991, "Ablution," In The Coptic Encyclopaedia, New York: Macmillan Publishing Co.

Bland, Kalman, 1983, “An Islamic Theory of Jewish History: The Case of Ibn Khaldun," Journal of Asian and A frican Studies, 18, 3-4, 189-197.

Blumenthal, David R., 2006, “Philosophic Mysticism: The Ultimate Goal of Medieval Judaism," In Esoteric and Exoteric Aspects in Judeo-Arabic Culture, edited by Benjamin Hary and Haggai Ben-Shammai, 1-18, Leiden and Boston: Brill.

Broydé, Isaac, 1901-1906, “Bahya ben Joseph Ibn Pakuda," In Jewish Encyclopedia, New York: Funk and Wagnalls.

1901-1906, "Sūfīsm," In Jewish Encyclopedia, XI: 579-81, New York: Funk and Wagnalls.

1901-1906, “Yudghanites," In Jewish Encyclopedia, XII: 624-5, New York: Funk and Wagnalls. 
Cairo Geniza manuscript, no. T.-S. 8. J. 26/19 of University Library Cambridge, Translated from Hebrew by Solomon Dov Goitein, 1953, "A Jewish Addict to Șūfīsm: In the Time of the Nagid David II Maimonides," The Jewish Quarterly Review, 44, 1, 46-49.

Cohen, Mark R., 2005, Poverty and Charity in the Jewish Community of Medieval Egypt, Princeton and Oxford: Princeton University Press.

Corbin, Henry, 1969, Creative Imagination in the Sufism of Ibn 'Arabi, Bollingen Series. Princeton: Princeton University Press.

Dunn, Marilyn, 2001, The Emergence of Monasticism: From the Desert Fathers to the Early Middle Ages, Malden, MA.: Blackwell.

Ernst, Carl W., and Bruce B. Lawrence, 2002, Süfi Martyrs of Love: The Chishti Order in South Asia and Beyond, New York: Palgrave Macmillan.

Fenton, Paul B, 1981, "Introduction," In The Treatise of the Pool (Al-Maqāla AlHawdiyya), edited by Paul Fenton, 1-53, London: The Octagon Press.

2003, "Judaism and Sūfīsm," In The Cambridge Companion to Medieval Jewish Philosophy, edited by Daniel H. Frank and Oliver Leaman, 201-217, New York: Cambridge University Press.

1998, “Abraham Maimonides (1186-1237): Founding a Mystical Dynasty," In Jewish Mystical Leaders and Leadership in the 13th Century, edited by Moshe Idel and Mortimer Ostow, 127-54, Northvale, N.J. and Jerusalem: Jason Aronson.

Firestone, Reuven, 1999, Jihad: The Origin of Holy War in Isläm, New York and Oxford: Oxford University Press.

2001, Children of Abraham: An Introduction to Judaism for Muslims, Hoboken, N.J.: American Jewish
Committee and KTAV Publishing House.

Glassé, Cyril, 1989, "Sūfīsm," In The Concise Encyclopedia of Islām, New York: Harper and Row.

Goitein, Solomon Dov, 1953, “A Jewish Addict to Sūfīsm: In the Time of the Nagid David II Maimonides," The Jewish Quarterly Review, 44, 1, 37-49. 1955, Jews and Arabs: Their Contacts through the Ages, New York: Schocken Books.

1971, A Medditeranean Society: The Jewish Community of the Arab World as Portrayed in the Documents of the Cairo Geniza, II, V, Berkeley: University of California Press.

Goldziher, Ignaz, 1893, "Ibn Hūd, the Mohammedan Mystic, and the Jews of Damascus." The Jewish Quarterly Review, 6, 1, 218-220.

Gonda, Jan, 1952, Sanskrit in Indonesia, Nagpur: International Academy of Indian Culture.

Harmless, William, 2004, Desert Christians: An Introduction to the Literature of Early Monasticism, Oxford and New York: Oxford University Press. 2008, Mystics, Oxford and New York: Oxford University Press.

Hodgson, Marshall G.S., 1977, The Venture of Islam: Conscience and History in a World Civilization (3 Vols.), Chicago and London: The Chicago University Press.

Holy Bible: The New Revised Standard Version, 1993, Catholic Edition, Nashville: Catholic Bible Press.

Ibn Ishāq, Muhammad, 1968 (1955), The Life of Muhammad (Sìrāt Rasūl Allāh), Translated by Alfred Guillaume, Lahore: Oxford University Press.

Ibn Paquda, Bachya ben Joseph, Duties of the Heart (Chovot Ha-Levavot), 2 volumes, Translated from Arabic to Hebrew by 
Yehuda ibn Tibbon from Hebrew to English by Daniel Haberman, 1996, Naunet, N.Y.: Feldheim Publishers.

JPS Hebrew-English Tanakh, Second Edition, 1999, Philadelphia: The Jewish Publication Society.

Kalus, Ludvik, and Claude Guillot, 2002, “La Jérusalem Javanaise et sa Mosquée Al-Aqsâ: Texte de Fondation de la Mosquée de Kudus Daté 956/1549," Archipel vol. 63: 27-56.

Karamustafa, Ahmet T, 2007, Sufism: The Formative Period. Edinburgh: Edinburgh University Press.

Kraemer, Joel L, 2003, “The Islāmic Context of Medieval Jewish Philosophy," In The Cambridge Companion to Medieval Jewish Philosophy, edited by Daniel H. Frank and Oliver Leaman, 38-68, New York: Cambridge University Press.

Labib, Subhi Y, 1991, "Saint Abraham," In The Coptic Encyclopaedia, I: 10-11, New York: Macmillan Publishing Co.

Lobel, Diana, 2007, A Sūfi-Jewish Dialogue: Philosophy and Mysticism in Bahya Ibn Paquda's Duties of the Heart. Philadelphia: University of Pennsylvania Press.

Maimonides, 'Obadyah, The Treatise of the Pool (Al-Maqāla Al-Hawdiyya), Translated and edited by Paul B. Fenton, 1981, London: The Octagon Press.

Meinardus, Otto F.A., 1999, Two Thousand Years of Coptic Christianity, Cairo and New York: The American University in Cairo Press.

Neusner,Jacob,1987, “Mishnahand Messiah," In Judaisms and Their Messiahs at the Turn of the Christian Era, edited by Jacob Neusner, William Scott Green and Ernest S. Frerichs, 265-282. Cambridge: Cambridge University Press.

Peters, Francis Edwards, 1994, A Reader of Classical Islām, Princeton: Princeton University Press.

Scholem, Gershom, 1941, Major Trends in Jewish Mysticism, Jerusalem: Schocken Books.

1965, On the Kabbalah and Its Symbolism, Translated by Ralph Manheim, New York: Schocken Books.

1987, Origins of the Kabbalah, Translated by Allan Arkush, Princeton, NJ: The Jewish Publication Society and Princeton University Press.

The Qur'ān: A New Translation, trans., M. A. S. Abdel Haleem, 2004, Oxford and New York: Oxford University Press.

Tottoli, Roberto, 2001-2006, "Bowing and Prostration," In Encyclopaedia of the Qur'ān, I: 254-255, Leiden, Boston, and Köln: Brill.

van Bruinessen, Martin, 1992, Tarekat Naqsyabandiyah Di Indonesia, Bandung: Mizan.

Wasserstrom, Steven M.,1995, Between Muslim and Jew, The Problem of Symbiosis under Early Islām, Princeton, NJ.: Princeton University Press.

Williams, Caroline, 2002, Islāmic Monuments in Cairo: The Practical Guide, Revised Edition. Cairo and New York: The American University in Cairo Press.

Yerushalmi, Yosef Hayim, 1996, Zakhor: Jewish History and Jewish Memory, Seattle and London: University of Washington Press. 